In the way of specific diversions, aside from the visit to the World's Fair, may be noted one or more evening lectures of general scientific interest, the annual dinners of the American Society of Naturalists and the Sigma Xi Honorary Scientific Society, each followed by an address by a prominent speaker, and the annual banquet of the trustees of the Missouri Botanical Garden, which is one of the notable events of the year, and for which personal invitations will be extended to as large a number of the distinguished guests of the city as can be provided for.

These statements should make clear that provision has been made for one of the most successful and one of the pleasantest meetings of the American Ássociation for the Advancement of Science and the American Society of Naturalists, with the many organizations that meet in affiliation with them; and the members of the bodies that are to meet in St. Louis should at once put their respective secretaries in possession of titles and abstracts of the papers that they propose presenting, so that the detailed programs may be prepared in the best manner.

In addition to the sections of the association, all of which except Section $K$ are to meet this winter, the following affiliated societies are to hold meetings in St. Louis during convocation week: The American Anthropological Association, The American Chemical Society, The American Mathematical Society-Chicago Section, The American Microscopical Society, The American Physical Society, The American Psychological Association, The American
Society of Naturalists-and with it the Central Branch, The American Society of Zoologists-Central Branch. The Association of Economic Entomologists, The Association of Plant and Animal Breeders, The Astronomical and Astrophysical Society of America, 'The Botanical Society of America, The Central Botanists' Association, The Fern Chapters, The Geological Society of America, The Sigma Xi Honorary Scientific Society, The Society for Horticultural Science and The Society for the Promotion of Agricultural Science. The Botanical and.Entomological Clubs of the association will also meet informally at times that will not conflict with the corresponding sections.

In our next issue the details of the arrangements for the meetings will be given, and the preliminary announcement, which will be mailed to members about the first of December, will contain full information as to hotels, railroad tickets, etc.

\section{SCIENCE AND MEDICINE IN THE MODERN UNIVERSITY.*}

Believe me, it is a difficult thing for a stranger, even at your invitation, to address you on an occasion like the present. So many significant events crowd in upon him and time for reflection is needed to weld into a connected whole the impression he would wish to offer to you. Not that the growth and doings of this university have not been followed and watched with interest by us in the old country. On the contrary, your activity has been felt, not

* Address given at the formal opening of the new laboratory for physiology, pathology and medicine of the University of Toronto, on October 1, 1903. 
only as a matter of mutual congratulation, but as a spur to arouse us to effort in our own similar pursuit of educational aims. But the stranger coming among you necessarily feels the shortcomings of his acquaintance with the details of these academic enterprises you have taken in hand. One advantage, however, is his. His view, gained from a distance, necessarily has freedom and truth of perspective that may give it a value in your eyes.

Some things lose by perspective. Some things, imposing when seen close to hand, dwindle when viewed from afar. Not so Canada. The perspective given by the width of the Atlantic is but an appropriate setting across which to view her greatness and her far-reaching activity. And this event, this academic celebration, this dies festus, in your university to-day, retains from afar off all the significance of a great event. It loses no tittle of its dignity and import when viewéd across ocean from the crowded turrets of the older Cambridge, or the hoary spires of Oxford. It shines, I assure you, like a beacon to the new university whose buildings are as yet unfinished on the hill above the port of Liverpool.

Coming from a region where history is long and the land little to this where written history is short and the expanse of land incomparably great, one realizes how relative is size. And in regard to the event of to-day the largeness of this country rises in my thought not as a matter of mileage, but-that with you more than with us in the old country, the size of tomorrow is vaster than the size of to-day. Each step of progress here, more than with us, has to be measured by its ample consequences in a more rapidly widening horizon of the morrow. These new laboratories have a field already demanding them, and a still larger lies before them in an immediate and historic future.

Biology is the study of life in regard especially to growth and organization. Every medical man is a biologist, and as a biologist it may be but natural if I regard to-day's event from a biological standpoint, and the community as an organism, and the university as a living organ, essential to the healthy life of the community.

Science-especially medical science-is growing in importance to the community. We must have organization in science as in industry. This university to-day makes provisions of first-rate importance for the organization of medical and allied sciences in the region which centers here. Capacity to rear and support men constitutes the ex. tent of a country, and population is the biological measure of the social organism. The ceaseless energy of the race has begun to plant a great population in this land. Growth, great and rapid, is inevitably before it. The growth of nations as of individuals requires the vigilance of guiding hands. Growth, for it to take its course rightly towards perfection, requires that provision for the security and expansion of the liberal arts and sciences forerun rather than halt behind the actual requirement of the hour. It is not only for their direct utilitarian service. They form a whetstone for man's most universal tool, his intellect, also a discipline for character, in the pursuit of truth for its own sake. Scientific truth, when found, has often proved unpalatable to man, as when it dethroned him from his fancied seat at the center of the whole perceptible universe, a universe he had imagined simply subservient to his needs; or again, as when it taught him that instead of being a creature altogether apart from the brutes, there are flesh and blood bonds between himself 
and them. Regardless of its cost to his cherished fancies, man strives for scientific truth. And, as the old Greeks said, this purpose puts him further from the brutes and nearer to the gods.

In nurturing science I would urge that a community cultivates more than mere utility. And even with regard to mere utility, as the fields of knowledge fall ripe under the ceaseless husbandry of the world's thought, those who would join in the great reaping, and not only glean where others reaped before them, must cultivate for themselves. To do this requires more than the devotion of individuals. It requires the intelligent cooperation of whole groups of individuals. Organized scientific inquiry becomes in advanced countries a conscious aim of the community as a community.

That society may draw due benefit from wells of natural knowledge, three kinds of workers have to stand side by side. First, the investigator, who, pursuing truth, extends discovery, with little or no reference to practical ends. He constitutes the fountain-head of the knowledge that is for distribution. Other hands may reap the harvest, but his set and rear the seed.

After the investigator comes the teacher. To him it belongs to diffuse the knowledge won. This honorable and difficult task receives its best reward in seeing the small spiritual beginnings of a pupil widen into the spiritual beginnings of a master. Thirdly, there is the applier. of natural. knowledge. His part consists in making scientific knowledge directly serve practical needs. It is this work which to the popular idea often represents the whole of science, or all of it that is commonly termed 'useful.' The practical results of this work are often astounding to those ignorant of the steps by which they have been reached. The greatest of these steps, however, is usually the first one, made in the laboratory of the investigator. These three coworkers are coequal in the priesthood. Science and the applications of science are one growth, united together even as the fruit and the tree. The proper hearthstone round which the community should group these laborers, laboring for a common end, is the university. There the sacred flame of learning is fed from many sides by many hands.

It is sometimes said that pursuit of science renders a man deaf to the appeals of practical life. That it tends to withdraw him from the everyday interests of the people. That I do not believe of any science, certainly not of biology and the medical sciences. From their very outset these subjects draw the mind toward study of an organization the most complex and the most perfect it can examine. The ancient simile that our school classic, Livy, drew between the human body and the body politic, the state, has not lost but won significance as the centuries have run. The achievement of the microscope has been the discovery that living things, whether plant or animal -all living things of more than minutest size-are commonwealths of individually living units. These cells, as they are called, are living stones that build the house of life. In that house each stone is a self-centered individually living microcosm individually born, breathing for itself, feeding itself, consuming its own substance in its living, and capable of and destined for an individual death. Each cell lives by exchanging material with the world surrounding it. In other words, its bulk depends on its surface. Hence, surface increasing as the square and volume as the cube, cell-size is circumscribed by tiny limits-microscopic limits. Had the dependence been greater than it is, and the average size of the cell less, and too small for resolution 
and discovery by the microscopes of seventy years ago, it is hard to imagine where biology would stand to-day. For two generatíons every biologist has been accustomed to think in terms of the cell theory. Every shred of the body he knows as an intricate interlacement, embodying cooperation and mutual support of associate thousands of individually existent cells. Division of labor. has gone on, and with it differentiation of structure; while this group of cells combines with its own inner life some special function subservient to the needs of the great commonwealth as a whole, another group is specialized for another duty again subservient to the general needs. Each organism, however complete its solidarity, each one of ourselves here, is built up of living myriads. Each such organism consisted at its outset of but a single cell, and from that in his life's growth have arisen the countless myriads composing him today. The blood relationship is close between all the cells of each individual body. The cells of our nerves, of our muscles, of our lime-hardened bones are all blood relations through one common ancestor. Yet so far has specialization of these unit lives gone on, so far does function reflect itself in microscopic form, that there is greater likeness between my nerve-cells and the nervecells of a fish than between my nerve-cells and my own muscle-cells-despite the blood relationship between these latter. And in the commonwealth of cells that constitute each one of us, goes forward day long, night long, as in the body politic, the birth of new units to replace the ones outworn, the subordination of many individual purposes to one, the sacrifice and destruction of the individual life for the benefit of the many.

Trained in study of such an organism, surely the biologist and the medical man will be the last to underrate the importance of organization to the community for the common weal. Therefore I am rejoiced, but I am not surprised, that it is your faculty of medicine which to-day, in its publicspiritedness, erects and instals these fine laboratories, this potent addition to the organization of your community, for its activities in medicine and biological science. I would also, as a friend among you, offer you my congratulations on the consolidation of your two schools of medicine. Union means not only greater strength, but the more effective application of that strength.

I need not to this assembly extol medicine. Many of her votaries are here; I venture to count myself as one. But to-day the relation toward her of education is a matter on which our minds are naturally set. Am I wrong if in regard to this it rises saliently to me that from the educational standpoint medicine, like Janus of old, in a good sense, bears a double face? On the one hand, she is an empiric. She has learned to cure by what the comparative psychologist calls the 'method of trial and error.' Her conquests over sickness were acquired purely as result of experience, without help either from a priori or from inductive reasoning. And great and glorious is the rôle of her achievement on these lines. Of her humanitarian triumphs probably still-certainly until a generation ago-the greater share is assignable to this part. The use of quinine in malaria, the curative effects of the iodides and various metals, the discovery of chloroform and ether as anesthetics, these and the names of a long line of famous physicians from the renaissance down to some as justly famous as the past, and with us now to-day, suffice to certify the inestimable gifts that medicine as empiric has given to mankind in his suffering. This face of medicine may well wear a garland.

In her other aspect, medicine is not an empiric, but a scientist. Who will refute 
me if $I$ assert that medicine is as well as an art a science? Somewhere it is said that woman is the last thing that man will ever civilize. So the scientific aspect, the male face of two visaged medicine, thinks of that female face, the empiric, with whom his lot is linked. He feels sometimes that his other half is the last thing science will ever render. wholly rational. By dint of patient toil he improves her practice by showing her a reason now and then. No sooner is that done than she is off on a fresh flight into the inexplicable, and he must cudgel his brains anew to find her a fresh logical position.

The feminine, ever youthful trait in medicine has to the student an undying charm. But, on the whole, the countenance of medicine has of recent years, for the student, become masculinely severe. This masculine head of medicine has indeed become the larger. Hydrocephalic in appearance though it may be, it is filled, not with water, but with reasoned facts. The development proceeds in the main from certain data acquired in the century just passed. For instance, the chemist, in discovering that all the million-sided chemical diversity of the perceptible universe is composed from a few-some seventy-substances, therefore called elemental, discovered also that living matter, instead of containing elements different from and subtler than those of the dead world, consists of just a few of the very commonest of those same ones. Further, the doctrine of the indestructibility of matter was demonstrated in a new form, namely, as the indestructibility of energy, and the convertibility of any one form of energy into other forms. Thus dead and living matter became united as subject material for study. It became really possible to consider the living body as a chemical and physical machine, a machine to which the laws of chemistry and physics can be applied.
But this scientific progress in medicine, fruitful of benefit to the community, lays on the community a burden of obligation. The empirical part of medicine is at once the most easy and the most difficult thing to teach. The preparation for learning it requires but little training in other subjects. Its facts lean on nothing but themselves.

With the scientific part of medicine it is different. That is based upon initiatory studies. Medicine, historically traced, we find first drawing help from the simplest and nearest at hand of these adjuvant studies. First she bent to the study of the gross form of the parts and organs of the body. The gross form of these is significant chiefly where they are machinery for application of mechanical powers. The greater part of the corporeal machinery is, however, not destined for such work, but has its purpose in processes chemical, thermal and electrical, to which-marvelous appendage-mentality is adjunct. Medicine in the course of the seventeenth and eighteenth centuries sucked dry for the most part what the study of the gross form of the body's parts could yield her. She then turned to the study of microscopic form-examined what Bichat first named the tissues, the fabric of the body. In so doing she came upon a great generalization, the cell doctrine, discovering an essential and visible similarity of microscopic structure in all that has life, differentiating it from all which has not life.

But even before the advent of the cell theory, medicine had begun to ask of chemistry what it could give her. With the discovery of oxygen and of the nature of combustion the links between biology and chemistry began to be tightly drawn. The young Oxford physician, Mayow, had performed the fundamental experiments on respiration and had discovered oxygen more than a century before Priestley and Lavoisier; but the time was not ripe until 
the stupendous work of Lavoisier had founded modern chemistry. The cell theory was from the first not only morphological but physiological. It meant for the application of chemistry to biology that the chemistry of the body or of one of its organs was a chemistry resultant from a thousand tiny living furnaces, individual seats of oxidation, deoxidation, polymerization, hydrolysis and what not.

Not only that, but the living laboratory of the cell itself manufactures even the medium in which the cells themselves exist: the saps and juices of the body. And we are beginning to know, thanks to pathology, that every species of animal produces an internal medium specific to itself. Further, your distinguished physiologist here, Professor Macallum, who has so revealed the distribution of the chemical elements within the cell, tells us that the internal medium which the cells of even the highest animal forms produce as appropriate for themselves, still approximates in its salts to the water of the ancient geologic seas in which their ancestry arose, and still reveals in fact the composition of that ancient ocean. In that respect these living cells, with all their influx of change, have been more durable and constant even than ocean itself. The contrast brings home to us a deep distinction between dead matter and living-the latter a moving equilibrium, gaining stability from the very motion of itself.

By Schwann and by Pasteur the bonds between chemistry and medicine were drawn still tighter through discoveries concerning those subtle influences named 'ferments.' Pathology, the study of these processes of the body in disease, even more than physiology, as yet, has drawn help from this part of modern chemistry. If the processes of health are in fact the resultant of the due cooperation of ten million little foci of healthy chemical action in the body, the processes of disease are similarly divisible, and have to be traced to the unhealthiness of certain of these minute centers of activity. How extreme is the importance of chemistry to modern medicine, no single statement can perhaps emphasize so well as this-that is, I believe, acknowledged on all hands-that in virtue of his chemistry, a chemist, Louis Pasteur, during the latter half of last century, was able to do more to alleviate the diseases of mankind and animals than any physician of his time.

To the physicist also medicine has made appeal. From him she has got understanding of the body's heat, the basis of the knowledge of fever; she has learned the intricacies of the mechanism of the eye and refined methods of examining that organ and of remedying many of its defects ; the laws that govern the circulation of the blood and the subtlest means of detecting the forces liberated in the working of the nervous system. In some cases, as sciences grow, their discoveries seem to sunder them the further one from another. In my belief, that merely shows they are then at the outset of their career. To-day we find physics and chemistry converging and conjoining within a field of physical chemistry. It early became convenient to have a specific name for living material, wherever found. The name given was protoplasm. It might have been better to call it $x$ or $y$, so far was it in many respects an unknown quantity. Instead of looking forward upon this material as a chemical entity, we incline now to regard it rather as a field for chemical action satisfying certain particular conditions. Probably discoveries regarding these conditions will fall to the physical chemist, perhaps in a future very near at hand. Probably such discoveries will be among the most valuable that medicine has yet received from any source. 
I have said enough to remind us how interlocked with science medicine has become. She is applying sciences to her own problems, and they form a vast capital fund from which she can draw wealth. To give instruction in this part of medicine, to turn out men trained in it, is now one of the duties of a medical school. The earnest student has a right to expect such training from his alma mater. But for it the requirements are importantly different from those that suffice as an introduction to empiric medicine. In the first place, as Pasteur said, we can not have the fruit without the tree. For scientific medicine the student must, perforce, be thoroughly trained in his sciences before he can really grasp instruction or truly profit from his medical teaching. One of the aims of his instruction in empiric medicine is to teach him to observe for himself; so in his instruction in scientific medicine, one of its aims is to enable him to apply science for himself. How small a fraction of all the realities of medical practise can be met in the few years of preparation of the student in the clinic as he passes through it in his school career! His teacher knows that well, and uses the cases there as types whereby the principles of medicine can be fixed as a beginning. The rest must be accomplished by the man himself, as his life's work. It is necessary that the student go forth from his school equipped not only with the present applications of science to disease, but so possessed of root principles of the sciences adjunct to medicine that he may grasp and intelligently use the further developments of scientific medicine after he is weaned from his instructors and the school. That is a way to obtain enlightened progress in professional practise. What truer safeguard can a man have, alone it may be, and isolated from the centers of knowledge, what truer safeguard can he have against all the pseudo-scientific quackeries of the day, than some real knowledge of the principles of the sciences, along whose lines the discoveries of medicine must develop?

Therefore it is that the burden of obligation falls heavily nowadays upon the teaching resources of every faculty of medicine worthy of the name. There is, in the first place, the burden of increased intellectual labor. Both for the learner and the teacher is this true. To seize the proffered assistance of these great and complex sciences is not always easy. These studies are more difficult than those that were needed once, and they take longer to acquire. The mere instrumentarium of modern chemistry and physics, as applied to medicine, and of physiology and pathology, and bacteriology, of itself suffices to bring conviction of the increased difficulty and longer training due for these studies now preparatory to medicine.

Further, these initiatory studies have become vastly more costly than was all that formerly was required. Experts have to be found who can devote themselves heart and soul and undividedly to their particular subject. Laboratories have to be erected and equipped, and on a scale that makes them a distinct feature of the modern world. Those that we see now here are models of their kind; wise foresight has planned them; public-spirited enterprise has constructed them accordant with that plan. Nor does the achievement end with their erection. The laboratories and their equipment are but the factory and the plant; both fail in their purpose if they halt for sustenance. And beyond that the likeness does not go. The factory, once started, if it be wanted, can expect to pay, to support itself. Not so the laboratory. The laboratory is both a school of instruction and a school of thought. Well, then, no higher instruction can be expected unaided to pay the expenses it 
involves; it can only do so at the expense of those who come to learn, and that is to put its teaching beyond the reach of all but the wealthier few. And the instruction is costly, for it has to be practical. And another source of expense is that the laboratory has not only to distribute knowledge, but to manufacture it. The duties of a university do not begin and end with the disciplinary and didactic. Besides schools of instruction, they must be schools of thought. To be this latter, the laboratory must pursue research. Even for the welfare of the class-teaching this is essential. Instructive lectures may be given by men of ability, the whole of whose knowledge is second-hand, but it is doubtful whether the real life of science can be fully felt and communicated by one who has not himself learnt by direct inquiry from nature. Nothing more augments the teacher's power of impressive and incisive teaching than to have faced problems of his subject himself as an original enquirer. And, after rudiments have been once fairly acquired, there is for good students no training equal to that given by following even a small research under an experienced leader.

So truly does the laboratory become a school of thought. The student should enter on his study of a natural science through the portal of its fundamental experiments. The attitude his mind thus takes is the true one-the only true one-for further insight into the subject. Too often humanistic studies at school have tended to kill the natural philosopher within the childto destroy that innate curiosity for facts, the healthy heritage of childhood. $\mathrm{He}$ leaves school a little book-man. Even as to the phenomena of nature, he has been insensibly led to ask for statements upon authority, rather than to turn his own senses and observation to the phenomena themselves. To learn a science or acquire an art resting upon sciences, the first thing to do is to look at the fundamental facts for oneself. Our great teachers of medicine teach upon this plan. They teach where they learned, not in the library, but from the bedside of the sick. In laboratories such as those raised here for pathology and physiology and hygiene students can learn these sciences as medicine is learned in the hospital ward by direct inquiry into nature. The teachers you give them are men who have won widely recognized distinction as themselves direct enquirers into nature. Worthy students will appreciate the double boon their alma mater gives them-the means of learning at first hand those secrets of nature which lie at the root of their craft's skill - and to learn them under guidance by men who excel in unraveling such secrets.

Only by enabling men to continue their learning after their teaching is over can we secure the greatest advantage any educational system can afford. Your laboratories here will encourage post-graduate work. We look with keen interest to the researches that will flow from them. No subjects offer finer fields for research than do the progressive studies, physiology, and pathology, to which your new university buildings are consecrated. And of the functions of a laboratory, research is not the least costly. We in the old country find that. Our central government has done little to support research. Our nation, proud of its success in things practical, has been prone to despise the abstract and the theoretical. We do so foolishly; we do so at our peril. Behind all practical application there is a region of intellectual action to which, though our practical men have contributed little, they owe the whole of their. supplies. Theory, if a goose, is the goose of the fairy tale that lays the golden eggs. No more such eggs if once you let her die. To speak of theoretic 
knowledge slightingly is for the lips of the fool. The value of abstract research to a country is becoming. more widely acknowledged among us than it was. Sir John Brunner said the other day, at Liverpool, that there was no better investment for a business man than the encouragement of scientific research, and that every penny of the wealth he possesses has come from the application of science to commerce and to manufacture. And we find that munificent citizens have and do come forward among us and meet by their individual gifts, the pressing needs in this respect of our community at large.

But we welcome a new era dawning on us. Liverpool, Birmingham, Sheffield and other great centers begin to regard the local university as an institution entitled to support from the public means, for instance, by subsidy from public rates. Such subsidies can be used also for studies which do not come within allotment from the smaller subsidy from the central government: medicine, for instance. Proud of the young universities - to which yours of Toronto is a time-honored veteran-communities and local governments are encouraging research within our universities. They do not expect such research to be able to pay its own way, but they recognize that indirectly it does pay the community that gives it a home. They feel it a duty which they owe themselves. Is not the university a part of their own life, and is not research a part of the university's life-blood? They feel it a right, due to their own higher selves. It stimulates progress. Supported by the large-handed sympathy of the community and the local government, it means quicker advance, both material and mental, it means invention, and it means medical discovery. And qui facit per alium facit per se, is a motto worthy of a state.

What, then, are finally the uses of these laboratories now opened by your univer- sity? They will assist in training men for various honorable callings, especially for that most ancient one of medicine. They will assist, no doubt, also to render life by practical applications of science still more different from what it was only a short generation ago. They will assist to bring home and distribute to your community treasures of knowledge from all the quarters of the globe. They will assist -and it is thought dear to a high-spirited people-to add, by their own contribution, to the sum total of the treasures of knowledge of the whole human race. 'Noblesse oblige' appeals not only to chivalrous individuals but to chivalrous nations.

Yet their highest office seems to me, perhaps, not even these high ones, but a more difficult still. Genius can not by any community, however. wealthy and powerful, be made to order. In biblical language, it is the gift of God. All a community can do toward obtaining it, be our riches and willingness a thousandfold what they are, is to ensure the rare and glorious plant a meed of freedom, light and warmth for blossoming upon our soil. Who can doubt, that in this population here genius exists - not sown, it is true, broadcast, for nowhere is it thus-yet existent, scattered up and down? This it is for the community to foster, to discover.

By the help of these finely built and finished laboratories this much in one direction can be done. The problem to which'a wise country turns is the discovery less of things than of men. By these laboratories, adequately supported, your community can create opportunity for the exercise of powers which come from sources within itself, but are utterly beyond its power to produce at will. Their loftiest function is creation of this opportunity. For that aim the studies in them must be followed with no single narrow technical purpose, but must be wide of scope and free of access 
to every rank of students. So shall these laboratories prove a corner-stone for the upbuilding of a temple of knowledge, and a touchstone for the best ore of intellect in all the width of this great land.

\section{S. Sherrington.}

UNiverstty College, LIVERPoOl.

\section{THE NEW AGRICULTURAL EDUCATION."}

THERE is now largely increased interest in agricultural education in all parts of the country. This is due in large measure to a radical change in the foundations of the system of agricultural education. In the past the courses of instruction were based on the sciences related to agriculture, whereas now they are being based on the science and art of agriculture itself. Owing chiefly to the researches of the agricultural experiment stations and kindred institutions in this country and abroad, there is now a distinct body of knowledge which may fairly be called the science of agriculture. This science treats of the production of plants and animals useful to man, and the uses of such plants and animals. It is divided into plant production, which includes agronomy (field crops), horticulture and forestry, zootechny or animal production; agrotechny or agricultural technology (including dairying, sugar-making, etc., adulteration of foods and feeding stuffs, etc.) ; rural engineering and rural economics.

This fact has lately been recognized in the reorganization of the United States Department of Agriculture, where we now have Bureaus of Soils, Plant Industry, Forestry and Animal Industry, in which are grouped a large number of scientists representing various specialties in agricultural science. These men now feel that they are working primarily as agricultural

* Summary of address at dedication of new agricultural building, New Hampshire College of Agriculture and Mechanic Arts, October 28, 1903. scientists rather than as botanists, chemists, physicists or physiologists. Their natural outlook is, therefore, in the direction of promoting the advancement of agricultural science and practise, and they are disposed to lay under contribution every science required to work out the complex problems of agriculture.

Many of our agricultural colleges are also being reorganized on this basis. A notable illustration of the results is found in the Illinois College of Agriculture, where there are now twenty men teaching different branches of the science of agriculture and the number of students has increased tenfold in four years.

While the number of students in the agricultural colleges has been relatively small, they have done a great work. From them have come in large measure the men who have made the science of agriculture, who have manned the experiment stations, who have brought about changes in our agricultural practise which have largely increased production, and, what is more important, have set our intelligent farmers on the highway of rational progress. These men have also laid the foundations for a system of agricultural education which is already affecting the thought and activity of hundred of thousands of farmers who never have been on the campus of an agricultural college, and which in the not distant future will directly touch the masses of our rural population.

For the leaders of our agricultural progress have learned, and the general public will soon learn, that the agricultural college is not the only institution required to give us a thoroughly effective system of agricultural education. And already representatives of the different institutions comprised in a comprehensive system of agricultural education are actually in operation in different parts of the country, so that we can now clearly understand what the American 